\title{
Introduction to 'Constitutional Work'
}

\author{
Jenny Morgan
}

Hilary and Kim have entitled the symposium 'Traversing Divides', and on re-reading the pieces that are to be discussed, or at least inspire the discussion in this coming session, I can see why.

Glancing at the papers to be examined by Jennifer Clarke, we see a traversing of the law-politics divide. In her work with Kim, and related work (and indeed in much of Deborah Cass's work), we see the lawfeminism divide traversed. And in her work on campaign financing, we see a close and fascinating reading of the history of campaign financing law, crossing the law-history divide.

And I think what this particular part of Deborah Cass's work which is to be discussed in this session demonstrates is that the divide is not a divide: law cannot be read without politics, history and, I would say, feminism - or at least asking the 'woman question'. So I wonder whether it is traversing divides, or rejecting divides ... However, I will leave that to my expert panel.

All three of our speakers were both colleagues and friends of Deborah's, as indeed was I. And thinking about chairing this session led me to reflect both on my own experience with constitutional law, and of course on Deborah Cass. I was taught constitutional law by Michael Coper, and it is terrific that he was able to join us for today's reflections. Michael used to share with us not only the reflections of others on the constitution for example, PP McGuinness's quizzical suggestion that if section 92 was so fundamental why wasn't it section 1 - but also the errors of previous students. The one that sticks in my mind was the student who, Michael insisted, had referred in an exam context, to the founding fathers as 
the 'pounding panthers'. And the pounding panthers made me think of Deborah. You might well ask why. I mused that one might describe Deborah's work as pounding - as insistent, as persistent, as resolute. And a panther is always sleekly elegant - and Deborah was always elegant in her presentation to the world.

Jennifer Clarke, in an aside, suggested that such a comment could only be made by someone who had not shared a house with Deborah. This is a comment that illustrates what was so very special about the day Hilary and Kim organised in celebration of Deborah and Deborah's work, and again consistent with the title of the symposium: the constant traversing of the public-private divide. The day gave us an opportunity to reflect on our personal and our intellectual relationships with Deborah; it allowed the personal into the intellectual, and the scholarly into the intimate in a way that academia rarely encourages. 
This text is taken from Traversing the Divide: Honouring Deborah Cass's Contributions to Public and International Law, edited by Kim Rubenstein, published 2021 by ANU Press, The Australian National University,

Canberra, Australia.

doi.org/10.22459/TD.2021.01 